Wolfgang Kempf (2009): A Sea of Environmental Refugees? Oceania in an Age of Climate Change. In: Elfriede Hermann, Karin Klenke und Michael Dickhardt (Hg.): Form, Macht, Differenz. Motive und Felder ethnologischen Forschens. Göttingen: Universitätsverlag Göttingen, 191-205. Doi: 10.17875/gup2020-1284

\title{
A Sea of Environmental Refugees? Oceania in an Age of Climate Change
}

\author{
Wolfgang Kempf
}

\section{Introduction}

Speaking on September 252008 during the 63rd session of the United Nations General Assembly, Anote Tong, President of the Republic of Kiribati, pointed out that climate change and rising sea levels constituted an existential hazard to his country, consisting as it chiefly did of low-lying coral atolls. Local measures designed to cope with the effects of climate change, President Tong stressed, would continue to be embraced and promoted wherever this was possible. Nevertheless, he regarded such measures as merely short-to-medium term solutions, since he had reached the conclusion that relocating the entire population was ultimately the only response. For that reason, he was recommending that a controlled process of work migration be initiated well in advance; only so could unplanned migration or flight by the inhabitants of his country be prevented in 50 or 60 years time. ${ }^{1}$

There can be no doubt that Pacific atoll states like Kiribati are especially exposed to the effects of climate change. The Fourth Assessment Report of the Intergovernmental Panel on Climate Change (IPCC) sets out the best scientific estimates currently available of likely risks posed by global warming to the islands of the Pacific Ocean (see Mimura et al. 2007). The report lists sea-level rise together with increased flooding, erosion and damage to infrastructure in the coastal zone; higher temperatures in sur- 
face waters, growing acidification of the sea, a bleaching or reduction of corals; a general increase in extreme weather events (like cyclones, storms, inundations and drought). There would be a drop in agricultural production and in fish stocks, impairment of water resources and, not least, a spike in vector- and water-borne diseases. Latest forecasts give every reason to fear that such grave inroads into the environmental and living conditions of low-lying islands in particular will have the long-range effect of rendering them uninhabitable for the majority of their inhabitants. Notwithstanding, voices are increasingly being heard which argue that resettlement should not be the only option canvassed; there can be no substitute, they say, for systematically investigating the entire gamut of adaptive strategies with regard to climate change.

The effects that climate change is predicted to unleash on Oceania and its peoples are of a spatial, ecological, social, political and economic nature. They should also be seen in the context of global connections, relations and inequalities. So my discussion of several of these possible transformations to Oceania takes its bearing from the complex terrain of research into spatiality and global entwinements - thematic fields to whose systematic clarification Brigitta Hauser-Schäublin's studies have made fundamental contributions (see Hauser-Schäublin and Braukämper 2002; Hauser-Schäublin and Dickhardt 2003).

In this essay, I shall ask how Epeli Hau'ofa's widely received model of a new Oceania stands up under the altered parameters of global warming and its predicted consequences for islands in the Pacific. Two opposed aspects are of importance here. In my view, Hau'ofa's critique of the diminishment and devaluation of the Pacific island world is as relevant as ever. Nor, however, should we be blind to the fact that smallness, in the context of debating likely strategies for coping with the regional effects of climate change, is one of the most important resources at the Pacific Islanders' disposal. In light of these considerations, I will offer a critical appraisal of the "environmental refugee" concept; then, in a final step, I will focus on the problem of privileging environmentally-induced migration or flight as the dominant form of adaptation to the anticipated consequences of climate change in the Pacific.

\section{From “Our Sea of Islands” to Smallness as a Resource}

Scenarios of forced migration, resettlement and diaspora as the inevitable outcome of climate change and rising sea levels have meanwhile gained entry into official as well as everyday discourses and practices of Pacific Islanders. The possibility of displacement and relocation is now an integral part of the future perspectives of a significant portion of the regional population. But what do these changed realities mean for the influential conceptualisation of a new Oceania put forward by Epeli Hau'ofa (1993a, 1993b, 1998) at the end of the twentieth century? Hau'ofa was himself critical of the hegemonic construction, advanced by westerners and indigenous elites alike, of the Pacific as a zone of 


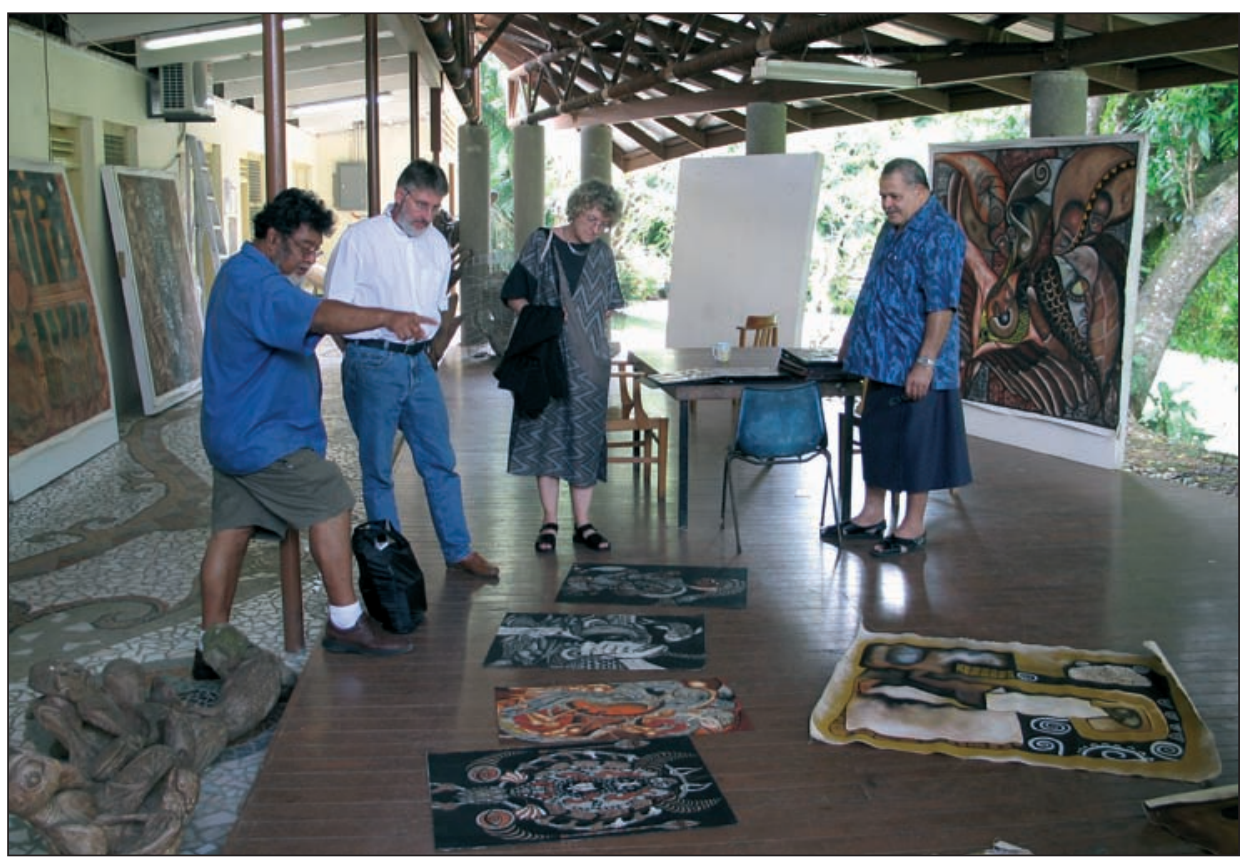

Meeting at the Oceania Centre for Arts and Culture, University of the South Pacific, Suva, Fiji (from left to right: Epeli Hau'ofa, Wolfgang Kempf, Brigitta Hauser-Schäublin, Ropate Qalo).

Photo: Elfriede Hermann, 2005.

fragmentation, isolation, resource paucity and dependency. The one-sidedness implicit in the perspective of "islands in a far sea", that is to say, scattered dots of terra firma in a huge ocean, represented, in his view, a systematic denigration and belittlement of the region, one that did no justice to the historical practice of entwinement and enlargement of Oceania effected by the Pacific Islanders. Hau'ofa opposed this with his own relational construct. He made the ocean an integral part of his counter-narrative, insisting that Oceania's peoples in the course of their long history of exploration and trade, of multiple ties, contacts and articulations - including the transnational migration flows of recent times - had moved to expand their oceanic world, and that they were still doing so. Thus he was able to stand up a new perspective, one with a positive twist, where the focus was not on scattered islands in a vast ocean but on Oceania as a relational structure, not on "islands in a far sea" but on "a sea of islands", not on restriction and smallness but on grandeur and enlargement (see especially Hau'ofa 1993a:7-8).

Academic debate of Epeli Hau'ofa's vision of a new Oceania includes three, often intersecting dimensions: acclaim, criticism and persistence. One need only look at the jubilee volume marking the $25^{\text {th }}$ anniversary of the University of the South Pacific (see Waddell, Naidu and Hau'ofa 1993), in which the key text "Our Sea of Islands" (together with replies by his academic colleagues at Laucala Campus) first appeared, 
to see the admixture of recognition and critical rejection that greeted Hau'ofa's work. Hau'ofa's model attracted recognition because his attempts to meld poetics, imagination, optimism and utopia were seen in a positive light as heralding a positive sense of identification with Oceania. On the other side, this alternative vision of an enlarged Oceania was criticised by many commentators as being based on romanticising and idealising ideas, and as such could not be squared with the basic facts of dependency, exploitation, proletarianisation and marginalisation - the lot of many Pacific Islanders living in a context of global currents and power relationships at home and abroad (see e.g. Chandra 1993; Griffin 1993; Naidu 1993).

Another objection was that Hau'ofa's version of a regional identity constituted by the ocean was evidently oriented, in no small degree, to maritime realities in Polynesia and Micronesia (see Griffin 1993:59). It was pointed out, from many quarters, that in the self-perceptions of a large portion of the Pacific peoples the sea played not nearly as central a role as this identity model envisaged, an objection that was later taken up by Houston Wood (2003), who argued that “[...] Hauofa's insistence on the urgent need for a regional identity remains persuasive. It seems likely, though, that the sea can form but a part, and not the whole, of a vision that will bring the region closer together" (Wood 2003:349). The gist of much of the critical reception accorded Hau'ofa's vision of a new Oceania was that it was just that, a vision - no doubt very important for the region as a whole, yet, when measured against real-world exigencies, not implementable on the ground.

The growing interest in Hau'ofa's model, its popularity in academic discourse and its continuing ability to engage the critics, is nonetheless remarkable. Thus, ever since "Our Sea of Islands" was reprinted in 1994 in the pages of The Contemporary Pacific, there have probably not been many years when this international journal has not carried a detailed discussion of Hau'ofa's concept of an enlarged Oceania or at least mentioned it in passing. Inspection of the current annual volume 21 (no.1, 2009) reveals no fewer than three contributions that refer more or less comprehensively to Hau'ofa's work (see Lilomaiava-Doktor 2009; Higgins 2009; Hanlon 2009). ${ }^{2}$ An important reason for this continuity can certainly be found in the fact that Hau'ofa's perspective corresponded to a general paradigm switch in the social and cultural sciences, in which movement, travel, migration, transnationalism and diaspora came to be seen as the constituting forces of place, culture and identity (see Clifford 1997:276-277). Dynamic conceptualisation of people identifying with specific places and/or territories frees up the analytic field of inquiry, allowing it to discern, not least, all those contacts, currents, relationships and embeddings that go well beyond the merely local. Hau'ofa also succeeded in encapsulating in memorable images, deploying a poetics all his own, "the end of insularity" (Nero 1997) and the transition to a relational way of conceiving Oceania.

Yet in the extremely numerous treatments of the last few years only rarely do we find an attempt being made to align Hau'ofa's concept of an enlarged Oceania with the new challenges that climate change means for the societies and nation states of the 
region, including their cultural legacies. ${ }^{3}$ This is all the more striking for the fact that, since the beginning of the 1990s, political representatives from several Pacific island states have been publicly drawing attention, and in a rhetoric growing ever sharper and more radical, to the dramatic consequences of climate change and rising sea levels for the people, islands and nations of Oceania. ${ }^{4}$ Thus, it is high time to take a closer look at the issues of Oceania, identity and climate change. One particularly promising line of inquiry is to focus on the metaphors of smallness characterising discourse about the effects of climate change on the Pacific Basin; for nowhere have small islands, small land masses, small-island states and microstates been talked of with such frequency, or with such a degree of self-evidency, than in this part of the world (see Barnett and Adger 2003; Dupont and Pearman 2006; Mimura et. al. 2007 inter al.). Moreover, smallness exists not simply as an attribution made from without; it exists also as a key element in the self-representations of Pacific Islanders. The tension between the view from without and the view from within calls for close study.

In an article on the disparity between western models of development and indigenous lifeways on the Pacific islands, Jon Barnett (2002) notes that precisely this call for measures to address climate change requires some basic rethinking. Citing Hau'ofa's alternative blueprint of an enlarged Oceanian world, Barnett urges that the specific skills, experiences and know-how of Pacific Islanders be recognised and co-opted, more than they have so far been, in projects developing the ability of local people to cope with climate change (cf. Sydee 2004). Heather Lazrus (2009) has argued along similar lines, citing her empirical work in Tuvalu in support of her own plea that the decision-making and coordination process in respect of both vulnerability to and adaption to climate change should not neglect local epistemologies and institutions (Lazrus 2009:245,247).

Another arena in which Oceania's belittlement is perpetuated involves the global media and the image propagated therein of how climate change will affect the region. Here the Pacific islands (or the Pacific island states) are usually assigned the role of confronting on a small scale what the world as a whole is soon going to confronting. Hence, Tebua Tarawa and Abanuea in Kiribati were described as having been among the first (uninhabited) islands to sink below the sea as a result of climate change; the people of the Carteret Islands (a remote chain of atolls in Papua New Guinea's Bougainville Province) as well as the resettled community of Lateu, a village on the island of Tegua (in Vanuatu) were arbitrarily portrayed as the (presumptive) first climate refugees of the twenty-first century; while the Pacific states of Tuvalu and Kiribati were tipped to become, by mid-century, the first nations in human history to vanish entirely from the map as a result of rising sea levels. The vignettes of climate change that are arranged and dramatized by the media obey a simple logic: harbingers, warning signs or tropes of climate change are taken as reflections - in microcosm, as it were - of the whole world. ${ }^{5}$

So, as I see it, it is both necessary and highly useful - on the one tack - to take on board Hau'ofa's critique of the belittlement and devaluation of Pacific islands, if 
only because it will hone our eye for reductionist constructions. On the other tack, I would caution that smallness need not always carry negative implications. Precisely in view of the fact that many islands are at acute risk from climate change and rising sea levels, smallness should be seen, I think, as constituting one of the most important argumentative resources in the political discourse of those contemporary Pacific societies that find themselves facing the prospect of forced migration and resettlement. That smallness need not only mean dependency and inferiority, but can also mean strength and the power to resist, was noted, as it happens, by some contributors to the original debate over Hau'ofa's "Our Sea of Islands" (see Ratuva 1993:96-97; Thaman 1993:4142). Vilsoni Hereniko (2001) has, for his part, also argued in much the same way. $\mathrm{He}$ suggested that Pacific Islanders explicitly embrace smallness as a key dimension of their regional geography, history, culture and society; also, that they should deploy it strategically to develop the forms of protection and resistance that Oceania, as a region, would need in an age of globalisation and climate change (Hereniko 2001:167-168).

Often we find that indigenous concepts of smallness in Oceania stem from creative appropriations and reworkings of hegemonic western discourses. Thus, for instance, the resettled Banabans on Rabi Island in Fiji, who were driven from their home island of Banaba (now part of Kiribati) when much of its terrain was rendered uninhabitable by phosphate mining, have integrated the aspect of smallness into their politics of identity and made it part and parcel of their culture of resistance (see Kempf 2004:170). They attribute their agency to their ability to involve outsiders, especially visitors from the former colonial powers, in a relational terrain intended to invoke the morally unacceptable condition of inferiority and unfulfilled reciprocity, even as it evokes empathy, concern and commitment on their part (see Hermann 2004, n. d.).

Just how important smallness can be as an argumentative resource in public discourse is also reflected in statements made by Pacific leaders, political and religious alike, highlighting the grave risks to their countries caused by global warming and rising sea levels, risks that are growing by the day. Saufatu Sopoaga, a former prime minister of the island state of Tuvalu, said for example:

[...] All I can say: please, help try and attend to this global phenomenon and contain it. Because we can do it. I mean, if the politicians of those industrialised countries have a will to help the minority populations of the globe, then let us do it! For the sake of us, small people - but also beautiful people. ${ }^{6}$

Representatives of the Pacific island states have, for many years now, wielded the political tool of asking the leading industrial countries, as the primary agents of the global green-house effect, to step up to the plate and shoulder their moral responsibilities. For - so the argument goes - despite the fact that the Pacific island states, due to their limited resources and economic structures, could never, not even by a long shot, generate enough green-house gases to harm the climate - and certainly not on the scale of the major industrial countries - it is those same island states who will be bearing the brunt 
of climate change, to the point where their very existence is imperilled (cf. Sydee 2004). In this environment of economic, social and political inequality, smallness for these disadvantaged island societies is a useful argumentative resource in the fight to secure great equity of burden-sharing. The existence of international organisations like the Alliance of Small Island States (AOSIS) and the Small Island Developing States (SIDS), which a considerable number of Pacific island states have joined, would seem to suggest that the discourse of smallness is being wielded to gain political weight.

Given that the overwhelming majority of Pacific Islanders are Christians, there can perhaps be heard, in these appeals by the "weak" to the humanity and decency of "the great", a distant echo of the Christian injunction to help the poor and downtrodden of the earth. Indeed, it is precisely the networks of Christian churches in the Pacific region and beyond that are playing an important role in highlighting how climate change will impact negatively on those living in the respective island states, and also in demanding a show of solidarity. At the heart of the lobby work done by the Christian churches is the ever-more-urgent issue of displacement and resettlement, especially in the case of those Pacific island states that will be most strongly exposed to climate change in the not-too-distant future.

\section{A Sea of Environmental Refugees?}

[...] there is a growing possibility that at least some of Tuvalu's population will become environmental refugees [...] (Connell 2004:271)

The atoll states of Tuvalu, Kiribati and the Marshall Islands, not to mention Tokelau and parts of Papua New Guinea, are threatened by the effects of climate change in a way that confronts many of those living in these Pacific regions with the vague prospect of displacement, resettlement and diaspora existence. Rising sea levels, in particular, might mean for a great deal of Pacific Islanders living in high-risk areas that they will one day be forced to exchange their homes for an uncertain future. Frequently we find that the issue of forced migration - the ultimate form of adjustment to climate-linked environmental changes - is linked in public discourse to talk of "environmental refugees" (or, more recently, of "climate refugees"). Although such talk may, on first inspection, seem unobjectionable enough, a little thought reveals it to be neither free of ambiguity nor uncontroversial. ${ }^{8}$ When, for instance, the ecologist Norman Myers (2002; see also Myers and Kent 1995) estimated that the global inroads of climate change would, over the long haul, turn some 200 million people into environmental refugees, thus posing grave security risks for the civil order of many nation states, it was no surprise to find such forecasts being taken with a grain of salt due to their speculative character and apocalyptic undertones. Critics like Richard Black (2001) and Stephen Castles (2002) objected, above all else, to the idea that a changing environment, however important, 
could be the sole cause of a global increase in forced migration. Environmental factors were, they assured us, always closely interwoven with political, social and economic factors. Both authors concluded that the concept of an "environmental refugee" was altogether too murky to be able to do analytic justice to the complexity of such reciprocities. Stephen Castles added that the concept was politically questionable as well, since it did not feature in the legal provisions of existing international agreements (especially the Geneva Refugee Convention of 1951), meaning that no recognition of refugee status could be expected: "Nobody gets asylum just because of environmental degradation" (Castles 2002:8).

Debates between "alarmists" and "skeptics", as Olivia Dun and Francois Gemenne (2008:10) once aptly dubbed the two contending camps, have meanwhile posted significant benchmarks for development of a moderate, praxis-oriented approach, primarily addressing problems in the conceptualisation and the international recognition of environmental refugees (see Bogardi and Warner 2009; Renaud et. al. 2007; OliverSmith 2009). All definitional blurring of the lines aside, a consensus exists between advocates of this approach that the number of environmental migrants or environmental refugees (now put at some 24-30 million people world-wide) is significantly higher than the number of officially recognised political refugees (some 8.4 million people) (see Renaud et.al. 2007:16-17). For this reason, it would seem a matter of urgent necessity to accord those displaced by environmental change the same legal status as that accorded political refugees. For parity to be achieved - so it is argued - either existing international agreements (such as the Geneva refugee convention) will need to be amended or new ones will need to be stood up. Either of these legal remedies will require intense prior study as to how environmental factors impact on human migration movements. Once this is known, the next step will be to precisely define, in terms of specific categories, those who have been forced to migrate, or flee, as a result of environmental change. If we agree to provisionally divide them into three categories - environmentally motivated migrants, environmentally forced migrants, and environmental refugees - this will serve to put in place an institutionalised practice and politics of evaluation, planning and co-ordination of environmentally caused migration processes on the national as well as the international level - with the stated goal of avoiding, as far as possible, either uncontrolled migration or mass flight (Renaud et. al. 2007:29-32). A way to achieve this goal was suggested by the current president of Kiribati, Anote Tong: his people should be helped by educational programmes to acquire, well in advance, the professional qualifications they will need in the event of having to quit their island homes - otherwise the I-Kiribati would suffer the fate of being destitute in somebody else's country. With the right skills, they could lead comfortable lives in the diaspora.

If the categorisation seems problematic, it isn't only because it is not at all clear who counts as an "environmental refugee". Critics have also taken umbrage at the dominant view that the predicted effects of climate change would turn islanders across vast areas of the Pacific (including entire atoll states) into environmental or climate refugees. 


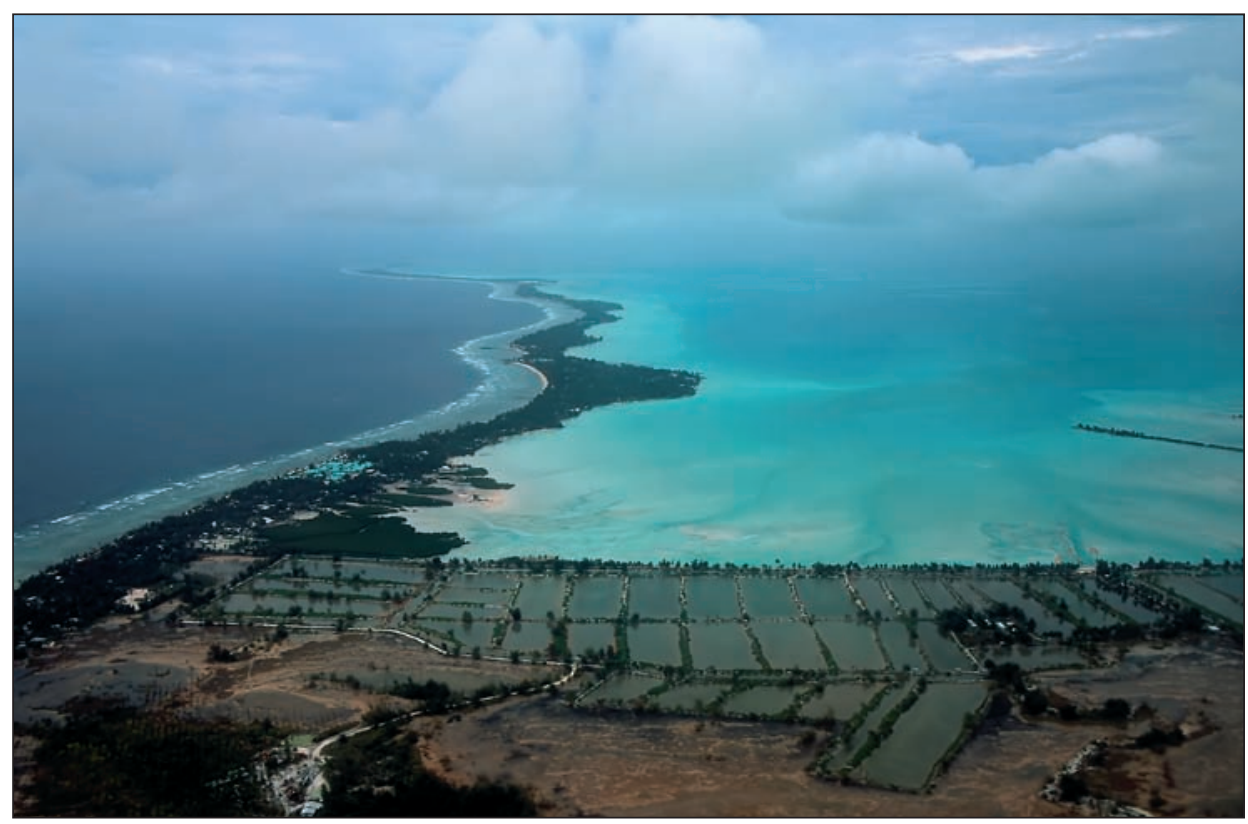

View of Tarawa, the urban main atoll of the Pacific state of Kiribati.

Photo: Wolfgang Kempf, 2005.

A general discourse that presents environmentally caused migration as a primary instrument of adaption constitutes, these critics say, an unnecessary narrowing of perspective. Other possible adaptive strategies have, they allege, been neither considered nor systematically researched. Taking such a narrow view is not justified because - firstly - the way the links between climate change and migration in Oceania are currently being portrayed owes more to alarmist journalism, cliché-ridden doomsday scenarios and speculative future projections than it does to scientifically backed findings. Second, to focus one-sidedly on migration as the core adaptive strategy will, we are told, undercut efforts to devise, develop and fund alternative strategies, including those that would deal with in situ ecological, social and economic challenges by focusing, first and foremost, on containment, resilience, protection and sustainability (see Barnett and Adger 2003; Connell 2003; Farbotko 2005; Gemenne and Shen 2009; Mortreux and Barnett 2009).

Hence, recent studies of climate change and migration in Oceania strive to give a more differentiated picture, showing Pacific Islanders as rather more than victims and displaced persons (see Farbotko 2005). Studies of Tuvaluans living in New Zealand indicate that although environmental factors can significantly influence the decision to migrate, no causal correlation can be demonstrated between climate change and migration patterns (Gemenne and Shen 2009:15,27). In Tuvalu itself, other than what popular simplifications suggest, the bulk of those living on Funafuti, the largest atoll, have 
no intention at all of emigrating (see Gemenne and Shen 2009; Mortreux and Barnett 2009). This rejectionist stance can be put down to the deep bonds many Tuvaluans feel for their land, culture, society and way of life. Colette Mortreux and Jon Barnett (2009:111) argue, therefore, that the right Tuvaluans have to go on living on their islands in future puts the international community under an obligation to do all it possibly can to avoid a future mass displacement of this island people. The primary imperative, one second to none, is to drastically cut green-house gas emissions on a global scale; next comes the funding of considered measures in support of effective adaption on the local level (Mortreux and Barnett 2009:106,111; cf. Lazrus 2009:248). The jury is still out on how these demands will resonate internationally. In any case, these recent studies of spatial identification and love of home in Pacific Islanders remind us how one-dimensional the dominant discourse is, with its exclusive commitment to displacement, migration and also environmentally or climate-induced flight as the central issues.

\section{Concluding Remarks}

When Epeli Hau'ofa coined the poetic image of a "sea of islands", he was repudiating, by thus conceptually enlarging Oceania, the hegemonic discourse of belittlement and devaluation of the Pacific island world. Just how important his counter-narrative is today as a critical corrective can be gauged from the representations of climate change and its implications for the region, which consistently adhere to a reductionist regime. On the other hand, commentators of Hau'ofa's vision of a new Oceania, as well as a chorus of political and religious leaders from the Pacific island states, have long been pointing out that smallness can also be a valuable resource for Pacific Islanders. We will need both points of view if we are to achieve a general understanding of the indigenous discourses and practices that are shaping and changing Oceania today.

Contemporary migration flows of Pacific Islanders to metropolitan countries like New Zealand, Australia and the United States belong, in Hau'ofa's counter-narrative, to the constitutive features of the ongoing enlargement of Oceania. But when, against a backdrop of many Pacific islands and their inhabitants being threatened by climate change and rising sea levels, there is talk of environmental and/or climate refugees, this enlargement of Oceania in consequence of mobility and migration, such as was proclaimed by Hau'ofa, takes an unexpected turn. In this connection, it needs first and foremost to be pointed out that not only the categories themselves, but also what we currently know about environmentally caused migration and/or flight, is undifferentiated and quite often empirically suspect. But if Pacific Islanders were, in future, to become more strongly affected by the inroads of climate change and if displacement, forced migration and/or mass evacuation were to become realities, there is no reason why this should not also be seen as an enlargement of Oceania. The challenge is to preserve and further develop the positives in Hau'ofa's vision - one of which I take to be a 
specific form of empowerment in the face of coarsened depictions of inferiority, helplessness and smallness - without necessarily losing sight of the cultural, social, political and economic hardships and losses. At the same time, smallness is one of the Pacific Islanders' key resources in their political battles with the international community. It is a resource that, on the one hand, encourages development of adaptive strategies and the preservation of island worlds; on the other hand, it can be expected to significantly contribute to the ongoing enlargement of Oceania.

\section{Acknowledgements}

An earlier version of this paper was presented in February 2009 to the "Global Warming in the South Pacific" session organised by Paul Shankman at the ASAO-Conference in Santa Cruz, California. I particularly wish to thank Paul Shankman, Michael Burton, Michael Goldsmith, Michael Dickhardt, Karin Klenke and Elfriede Hermann for their helpful suggestions and comments.

\section{Notes}

1 See "Republic of Kiribati. Statement by His Excellency Anote Tong President of the Republic of Kiribati. The General Debate of the 63rd Session of the United Nations General Assembly, Thursday, 25 September 2008". See in this connection also an interview ("Climate Change...Nobody is Immune") with Anote Tong, President of Kiribati, in the July 2008 edition of the magazine Islands Business.

2 Sadly, Professor Epeli Hau'ofa passed away in Suva on 11 January 2009. His vision of "our sea of islands" will certainly continue to be honoured, and not least in the pages of this journal.

3 There are authors who, in the context of the present debate, have noted the threat facing the Pacific islands and their inhabitants, alluding to it, if only briefly, as a critical aspect of the powerful global influences operating in the region (see e.g. Naidu 1993:53; Subramani 2001:157; Hereniko 2001:167-168). Moreover, the journal The Contemporary Pacific occasionally carries pieces touching on this thematic complex in one way or another (see e.g. Chambers and Chambers 2007; Strokirch 2007).

4 See in this connection statements by the Pacific Islands Forum (PIF) from the years 1991, 1992 and 1997 concerning the threat posed to the Pacific region by global warming and rising sea levels (Shibuya 2004:106,110).

5 In the case of Tuvalu, John Connell (2003) has analysed very cogently the symbolic function attributed to this atoll state by the international media: "Tuvalu has become a synecdoche: a representation of all threatened islands and greenhouse disasters" (Connell 2003:104; cf. Lazrus 2009:248). Even proponents of advocacy anthropology fall back at times on such rhetorical devices, as, for example, can be seen in the following formulation: "Islands are home to unique forms of life. [...] These miniature worlds serve as our canary in the coal mine for climate change, warning of the destructive impacts well underway" (Barker 2008).

6 The quotation is taken from "Der Untergang von Tuvalu" ["The End of Tuvalu"], a documentary film made by Marianne Aschenbrenner and Bernd Niebrügge in 2003. Saufatu 
Sopoaga was elected prime minister of this island state in August 2002, being finally toppled by a vote of no confidence in 2004 (see on this point also Taafaki 2007:278).

7 Togain an idea of the specific discourses, appeals and solidarity structures of Christian churches throughout the Pacific in respect of climate change, see for instance: Johnson, Natasha "Tuvalu seeks mass migration" on ABC broadcast, 7:30 Report, 16 July 2003, transcript at <http://www.abc.net.au/7.30/content/2003/s903787.htm> [12.09.2009]; Cain, Kim "Noah's rainbow worries some Tuvalu church leaders", 09 September 2008, Journey Online, Queensland Uniting Church, available at <http://www.journeyonline.com.au/showArticle.php?categoryId=2\&articleId=1686> [12.09.2009]; "Statement from the $9^{\text {th }}$ Assembly of the Pacific Conference of Churches on Climate Change", 08 September 2007, available at <http://www.emw-d.de/fix/files/final_statement_9th_PCC-Assembly07.pdf> [12.09. 2009]; or "Pacific churches call for global solidarity on climate change", 27 November 2008, available at <http://www.ekklesia.co.uk/node/8077> [12.09.2009]; see also Loughry and McAdam (2008:52).

8 Etienne Piguet (2008:1) espouses the view that "climate refugee" is a somewhat more precise concept to work with here than "environmental refugee". Since, however, he does not say why this is so, one should be cautious about injecting the former into the current debate.

\section{References}

Aschenbrenner, Marianne and Bernd Niebrügge (2003) Der Untergang von Tuvalu. Documentary Film (41 Minutes).

Barker, Holly M. (2008) Vulnerable Island Nations at Mercy of World's Polluters. Pacific Islands Report November 2008:1-5. Electronic document: <http://archives. pireport.org/archive/2008/November/11-05-com.htm> [07.09.2009].

Barnett, Jon (2002) Rethinking Development in Response to Climate Change in Oceania. Pacific Ecologist 1:25-28.

Barnett, Jon and Neil Adger (2003) Climate Dangers and Atoll Countries. Climatic Change 61(3):321-337.

Black, Richard (2001) Environmental Refugees: Myth or Reality? UNHCR Working Papers 34:1-19.

Bogardi, Janos and Koko Warner (2009) Here Comes the Flood. Nature Reports Climate Change 3:9-11.

Castles, Stephen (2002) Environmental Change and Forced Migration: Making Sense of the Debate. UNHCR Working Papers 70:1-14.

Chambers, Anne and Keith S. Chambers (2007) Five Takes on Climate and Cultural Change in Tuvalu. Contemporary Pacific 19(1):294-306. 
Chandra, Rajesh (1993) Where Do We Go From Here? In: Eric Waddell, Vijay Naidu and Epeli Hau'ofa (eds): A New Oceania: Rediscovering Our Sea ofIslands, pp. 76-81. Suva: School of Social and Economic Development, USP.

Clifford, James (1997) Routes: Travel and Translation in the Late 20th Century. Cambridge, MA: Harvard University Press.

Connell, John (2003) Losing Ground? Tuvalu, the Greenhouse Effect and the Garbage Can. Asia Pacific Viewpoint 44(2):89-107.

Connell, John (2004) Environmental Change, Economic Development, and Emigration in Tuvalu. In: Victoria S. Lockwood (ed.): Globalization and Culture Change in the Pacific Islands, pp. 260-272. Upper Saddle River, New Jersey: Pearson, Prentice Hall.

Dun, Olivia and François Gemenne (2008) Defining 'Environmental Migration'. Forced Migration Review 31:10-11.

Dupont, Alan and Graeme Pearman (2006) Heating Up the Planet: Climate Change and Security. Double Bay, NSW: Lowy Institute for International Policy (Lowy Institute Paper 12).

Farbotko, Carol (2005) Tuvalu and Climate Change: Constructions of Environmental Displacement in the Sydney Morning Herald. Geografiska Annaler (Series B) $87(4): 279-293$.

Gemenne, François and Shawn Shen (2009) Tuvalu and New Zealand: Case Study Report. 32 pages. Environmental Change and Forced Migration Scenarios (EACHFOR). Available at <http://www.each-for.eu/documents/CSR_Tuvalu_090215. pdf $>$ [07.09.2009].

Hanlon, David (2009) The "Sea of Little Islands": Examining Micronesia's Place in "Our Sea of Islands". Contemporary Pacific 27(1):91-110.

Hau'ofa, Epeli (1993a) Our Sea of Islands. In: Eric Waddell, Vijay Naidu and Epeli Hau'ofa (eds): A New Oceania: Rediscovering Our Sea of Islands, pp. 2-16. Suva: School of Social and Economic Development, USP.

Hau'ofa, Epeli (1993b) A Beginning. In: Eric Waddell, Vijay Naidu and Epeli Hau'ofa (eds): A New Oceania: Rediscovering Our Sea of Islands, pp. 126-139. Suva: School of Social and Economic Development, USP.

Hau'ofa, Epeli (1994) Our Sea of Islands. Contemporary Pacific 6:148-161.

Hau'ofa, Epeli (1998) The Ocean in Us. Contemporary Pacific 10(2):391-410.

Hauser-Schäublin, Brigitta and Ulrich Braukämper (eds) (2002) Ethnologie der Globalisierung: Perspektiven kultureller Verflechtungen. Berlin: Reimer. 
Hauser-Schäublin, Brigitta and Michael Dickhardt (eds) (2003) Kulturelle Räume Räumliche Kultur. Zur Neubestimmung des Verhältnisses zweier fundamentaler Kategorien menschlicher Praxis. Münster et.al.: Lit.

Hermann, Elfriede (2004) Emotions, Agency and the Dis/placed Self of the Banabans in Fiji. In: Toon van Meijl and Jelle Miedema (eds): Shifting Images of Identity in the Pacific, pp. 191-217. Leiden: KITLV Press.

Hermann, Elfriede (n.d.) Empathy, Ethnicity, and the Self Among the Banabans in Fiji. In Douglas Hollan and C. Jason Throop (eds): The Lives of Others: The Culture and Ethnopsychology of Empathy in the Pacific.

Hereniko, Vilsoni (2001) David and Goliath: A Response to “The Oceanic Imaginary". Contemporary Pacific 13(1):163-168.

Higgins, Katherine (2009) The Red Wave Collective: The Process of Creating Art at the Oceania Centre for Arts and Culture. Contemporary Pacific 27(1):35-70.

Kempf, Wolfgang (2004) The Drama of Death as Narrative of Survival: Dance Theatre, Travelling and Thirdspace among the Banabans of Fiji. In: Toon van Meijl and Jelle Miedema (eds): Shifting Images of Identity in the Pacific, pp. 159-189. Leiden: KITLV Press.

Lazrus, Heather (2009) The Governance of Vulnerability: Climate Change and Agency in Tuvalu, South Pacific. In: Susan A. Crate and Mark Nuttall (eds): Anthropology and Climate Change: From Encounters to Actions, pp. 240-249. Walnut Creek: Left Coast Press.

Lilomaiava-Doktor, Sailiemanu (2009) Beyond "Migration": Samoan Population Movement (Malaga) and the Geography of Social Space (Vā). Contemporary Pacific 21(1):1-32.

Loughry, Maryanne and Jane McAdam (2008) Kiribati - Relocation and Adaption. Forced Migration Review 31:51-52.

Mimura, Nobuo et. al. (2007) Small Islands. In: Martin Parry et. al. (eds) Climate Change 2007: Impacts, Adaptation and Vulnerability. Contribution of Working Group II to the Fourth Assessment Report of the Intergovernmental Panel on Climate Change, pp. 687-716. Cambridge: Cambridge University Press

Mortreux, Colette and Jon Barnett (2009) Climate Change, Migration and Adaptation in Funafuti, Tuvalu. Global Environmental Change 19(1):105-112.

Myers, Norman and Jennifer Kent (1995) Environmental Exodus: An Emergent Crisis in the Global Arena. Washington: The Climate Institute. 
Myers, Norman (2002) Environmental Refugees: A Growing Phenomenon of the $21^{\text {st }}$ Century. Philosophical Transactions of the Royal Society B 357:609-613.

Naidu, Vijay (1993) Whose Sea of Islands? In: Eric Waddell, Vijay Naidu and Epeli Hau'ofa (eds): A New Oceania: Rediscovering Our Sea of Islands, pp. 49-55. Suva: School of Social and Economic Development, USP.

Nero, Karen L. (1997) The End of Insularity. In: Donald Denoon (ed.): The Cambridge History of Pacific Islanders, pp. 439-467. Cambridge: Cambridge University Press.

Oliver-Smith, Anthony (2009) Climate Change and Population Displacement: Disasters and Diasporas in the Twenty-first Century In: Susan A. Crate and Mark Nuttall (eds): Anthropology and Climate Change: From Encounters to Actions, pp. 116136. Walnut Creek: Left Coast Press.

Piguet, Etienne (2008) Climate Change and Forced Migration. UNHCR Research Paper 153.

Ratuva, Sitiveni (1993) David Vs Goliath. In: Eric Waddell, Vijay Naidu and Epeli Hau'ofa (eds): A New Oceania: Rediscovering Our Sea of Islands, pp. 94-97. Suva: School of Social and Economic Development, USP.

Renaud, Fabrice, Janos Bogardi, Olivia Dun and Koko Warner (2007) Control, Adapt or Flee: How to Face Environmental Migration? InterSecTions 5/2007. United Nations University: Institute for Environment and Human Security.

Shibuya, Eric (2004) The Problems and Potential of the Pacific Islands Forum. In Jim Rolfe (ed.) The Asia-Pacific: A Region in Transition, pp. 102-115. Honolulu: AsiaPacific Center for Security Studies.

Strokirch, Karin von (2007) The Region in Review: International Issues and Events 2005-2006. Contemporary Pacific 19(2):551-557.

Subramani (2001) The Oceanic Imaginary. Contemporary Pacific 13(1):149-162.

Sydee, Jasmin (2004) How are the Pacific Island Countries Attempting to Fight Global Warming? Available at <http://www.uow.edu.au/arts/research/ejournal/archives/ jun04/jsarticle.pdf> [26/02/2009].

Taafaki, Tauaasa (2007) Polynesia in Review: Issues and Events, 1 July 2005 to 30 June 2006. Tuvalu. Contemporary Pacific 19(1):276-286.

Wood, Houston (2003) Cultural Studies for Oceania. Contemporary Pacific 15(2):340374. 